\begin{tabular}{|c|c|c|}
\hline ; & 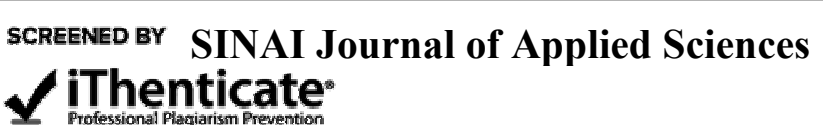 & $\begin{array}{l}\text { ARU-EGYPT } \\
\text { SUAS }\end{array}$ \\
\hline
\end{tabular}

\title{
TOMATO- WATER RELATIONSHIPS RESPONSE TO IRRIGATION WATER REGIMES AND DRIP IRRIGATION APPLICATIONS
}

\author{
Esraa A. Rehema ${ }^{1 *}$; M.S. El Kassas ${ }^{1}$, A.A.S. Shalaby ${ }^{2}$ and A.A. El-Sebsy ${ }^{1}$
}

1. Dept. Soil and Water, Fac. Environ. Agric. Sci., Arish Univ., Egypt.

2. Dept. Chem. and Nat. Lands, Cent. Des. Res., Minis. Agric. and Land Reclam., Egypt.

\begin{abstract}
Field experiment was carried out at the Experimental Farm, Faculty of Environmental Agricultural Sciences, Arish University, El-Arish, North Sinai Governorate, during two successive seasons, 2014/2015 and 2015/2016. The experiment was investigated to study the response of tomato fruit yield, tomato actual evapotranspiration, water use efficiency, the crop water productivity, water production function and crop response factor to water irrigation regimes with and without mulching under surface and subsurface drip irrigation systems. Each irrigation system consisted of 9 treatments with the addition irrigation water as crop evapotranspiration percentage $(\mathrm{ETc} \%)$ were subjected throughout the whole growth season or individually subjected throughout various growth stages. Increasing the deficit irrigation levels, significantly decreased tomato fruit yield, total tomato actual evapotranspiration, water use efficiency. Total tomato actual evapotranspiration values with mulching by black plastic sheet were significant less than those values obtained under without mulching, while tomato fruit yield and water use efficiency values(WUE) with mulching were significantly more than those obtained without mulching.
\end{abstract}

Key words: Fruit yield, total tomato actual evapotranspiration, water use efficiency, water irrigation regimes, mulching, surface and subsurface drip irrigation.

\section{INTRODOCTION}

In arid and semi-arid regions, the impact of water stress on yield is depending on the quality and quantity of irrigation water, crop, plant growth stage, soil type, climate and irrigation system as well as the time of exposure to water stress. Also, Doorenbos and Kassam (1986) added that the water stress effects on growth and yield are depending on plant species and variety. Moreover, sensitivity to drought varies by the development stage. Agbna et al. (2017) noted that deficit irrigation is an optimization strategy that allows to some extent of water stress during a certain cropping stage or the whole season without a significant reduction in yield. On the other hand, Saad et al. (2018) in their study to investigate the influence of deficit irrigation water of 0,25 and 50 ETc applied at different growth stages on tomato fruit yield $\left(\mathrm{kg} / \mathrm{m}^{2}\right)$ values as well as control treatment; the tomato plants were irrigated by the full irrigation (100\% ETc) during the whole growth season, they observed that tomato fruit yield significantly reduced compared to tomato fruit yield value of control treatment under studied irrigation systems. They added that the reduction percentage values in tomato fruit yield ranged between 9.1 to $41.5 \%$. Also they

\footnotetext{
* Correspondence author: Tel: +201027466548

E-mail address: esraaadel860@yahoo.com
} 
found that the flowering growth stage of tomatoes was the highest stage influenced by deficit irrigation depths especially at deficit irrigation of $50 \%$ ETc.

Sharma et al. (2014) observed that the deficit irrigation practice saved more than $40 \%$ of irrigation water with a significant reduction yield. On the other hand, Nangare et al. (2016) reported that although regulated deficit irrigation did not affect the yield at regulated deficit irrigation with $80 \%$ from full irrigation, there was a loss of approximately one fourth of the marketable fruit yield with regulated deficit irrigation with $60 \%$ from full irrigation compared to the full irrigation. Agbna et al. (2017) noted that deficit irrigation significantly increased the fruit quality compared to the full irrigation regime. Zhang et al. (2017) noted that when water stress was increased, the fruit yield of tomatoes decreased evidently with decreasing amount of irrigation water. Severe water stress affected the multiplication and expansion of the cells during all growing stages.

Zotarelli et al. (2009) noted that adoption of surface and sub-surface drip irrigation system along with plastic mulch, save irrigation water by $15-51$ and $7-29 \%$, respectively with $11-80 \%$ more tomato fruit yield compared to the conventional irrigation system. Biswas et al. (2015) noted that the maximum yields of tomato were 81.12 and 79.49 ton $\mathrm{ha}^{-1}$ under polyethylene and straw mulch, respectively, with water supply of $50 \%$ crop water requirement under drip system. Rahman et al. (2016) pointed out that the maximum tomatoes fruit yield was recorded from black polyethylene sheet treatment $\left(2.46 \mathrm{~kg} \mathrm{plant}{ }^{-1}\right)$, while the minimum tomatoes fruit yield $(2.16 \mathrm{~kg}$ plant $^{-1}$ ) was obtained from control (without mulching). Singh et al. (2017) pointed out that black color synthetic mulch significantly increased yield of tomatoes.

Hanson and May (2004) found that tomato yield increased under the drip systems compared to the sprinkler systems with similar amounts of applied water. The higher yields of the drip irrigation suggest increased evapotranspiration compared to sprinkler irrigation. However, because higher yields occurred under subsurface drip irrigation, the same total yield could be grown on fewer hectares compared to sprinkler irrigation, which would save water. Also, Abuarab et al. (2013) noted that the corn yield under subsurface irrigation treatment was significantly higher than the drip irrigation treatment. On the contrast, El-Mokh et al. (2014) pointed out that in both seasons, subsurface drip irrigation increased potato fruit yield compared with the surface drip irrigation but the difference between both irrigation methods was no significant for all irrigation treatments. On the other hand, Hassanli et al. (2009) pointed out that the pressure irrigation systems, i.e., subsurface drip irrigation and surface drip irrigation led to a greater corn yield compared to the surface method furrow irrigation. Saad et al. (2018) found that the tomato fruit yield values under drip irrigation system were significantly higher than that obtained under gated pipe irrigation system.

Aziz et al. (2013) indicated that for tomatoes overall, the $100 \%$ of available water treatment had the highest crop water requirement during the growing season, while the 75 of available water and $50 \%$ of available water treatment had the second highest performance. Zhang et al. (2017) pointed out that the tomatoes ETa generally decreased with decreasing amount of irrigation water during both seasons. 
Aziz et al. (2013) pointed that the 50\% of available water treatment condition gave higher tomatoes WUE as opposed to $100 \%$ of available water treatment and $75 \%$ of available water treatment, but the difference was not significant. The percent of increase in WUE under $50 \%$ of available water treatment was only $16.6 \%$ and $24.6 \%$ for tomatoes as compared with the $100 \%$ of available water and $75 \%$ of available water treatment. Arbex et al. (2017) showed that water deficit increased the water use efficiency of tomatoes by $20 \%$ compared to control condition (full irrigation). While, Delazari et al. (2019) reported that the maximum the higher tomatoes efficiency in the use of water corresponded to $50 \%$ ETc.

On the other hand, Mukherjee et al. (2010) noted that the highest WUE value of tomatoes $\left(21.6 \mathrm{kgm}^{-3}\right)$ was noted when two irrigations were applied to the tomato yield and the same was at the lowest point when five irrigations were supplied to the crop. Patanèa et al. (2011) concluded that save water improving its use efficiency in processing tomato but water should be applied to the crop throughout the whole growing season, even at a low rate, 50\% crop evapotranspiration (ETc), to achieve adequate fruit yield, minimizing fruit losses and maintaining high fruit quality levels.

Biswas et al. (2015) noted that higher WUE of tomatoes were obtained from mulch treatments with $50 \%$ crop water requirement. Polythene mulch performed better in terms of yield and water use efficiency. Poornima et al. (2016) pointed out that drip irrigation in combination with plastic mulch was found to be more effective irrigation method in improving WUE of cucumber and increasing crop yield. Banerjee et al. (2016) noted that mulching treatment recorded 34\% higher WUE of potato than no-mulch condition.
Taylor et al. (2006) pointed out that subsurface drip irrigation improves water use efficiency by allowing the application of a small quantity of water directly at the root zone and maintaining this layer at suitable soil water.

\section{MATERIALS AND METHODS}

Field experiment was carried out at the Experimental Farm, Faculty of Environmental Agricultural Sciences, Arish University, North Sinai Governorate, Egypt during two successive seasons, 2014and 2015. The Experimental Farm is located at latitude of $31^{\circ} 07^{\prime} \quad 59^{\prime \prime} \mathrm{N}$ and longitude of $33^{\circ} 49^{\prime} 40^{\prime \prime}$ E and $17 \mathrm{~m}$ above sea level. The experiment was investigated to study the response of tomato actual evapotranspiration, water use efficiency, the crop water productivity, water production function and crop response factor to water irrigation regimes with and without mulching under surface and subsurface drip irrigation systems. Nine irrigation treatments, where, addition of irrigation water as crop evapotranspiration percentage $(\mathrm{ETc} \%)$ were subjected throughout the whole growth season or individually subjected throughout various growth stages are illustrated in Table 1. Surface and subsurface drip irrigation systems were used in this investigation. Black plastic sheet was used for mulching. Each experiment plot included 3 lateral lines as replicates. Tow deficit irrigation levels of 25 and 50\% from crop evapotranspiration, ETc, and 3 applied irrigation water periods were individually subjected throughout the development, flowering and harvesting growth stages and the same deficit irrigation levels were subjected throughout whole growth season (during the growth season period) as well as the deficit irrigation level of $0 \%$ ETc, control treatment, was subjected throughout 
Rehema, et al.

Table 1. Meteorological data of Experimental Farm (mean of ten years)

\begin{tabular}{|c|c|c|c|c|c|c|c|c|c|c|c|}
\hline \multirow{3}{*}{ Month } & \multirow{2}{*}{\multicolumn{3}{|c|}{ Temperature $^{\circ} \mathrm{C}$}} & \multirow{3}{*}{$\begin{array}{c}\text { p } \\
\text { value }^{*}\end{array}$} & \multirow{3}{*}{$\begin{array}{c}\text { Humidity } \\
(\%)\end{array}$} & \multirow{3}{*}{$\begin{array}{l}\text { Wind speed } \\
\text { km/day }\end{array}$} & \multirow{3}{*}{$\begin{array}{l}\text { Sunshine } \\
\text { (Hour) }\end{array}$} & \multirow{3}{*}{$\underset{\mathrm{MJ} / \mathbf{m}^{2} / \mathrm{day}}{\operatorname{Rad}}$} & \multicolumn{3}{|c|}{ ETo, mm/day } \\
\hline & & & & & & & & & \multicolumn{2}{|c|}{$\begin{array}{c}\text { Estimating } \\
\text { equation }\end{array}$} & \multirow[b]{2}{*}{ Average } \\
\hline & Min. & Max. & Mean & & & & & & $\begin{array}{l}\text { Blaney- } \\
\text { Criddle }\end{array}$ & $\begin{array}{l}\text { Penman- } \\
\text { Monteith }\end{array}$ & \\
\hline January & 8.6 & 23.0 & 15.8 & 0.24 & 70.0 & 209.0 & 6.2 & 11.4 & 2.05 & 2.44 & 2.25 \\
\hline February & 8.9 & 23.8 & 16.4 & 0.25 & 69.0 & 244.0 & 6.0 & 13.2 & 2.30 & 2.96 & 2.63 \\
\hline March & 14.5 & 27.1 & 20.8 & 0.27 & 67.0 & 253.0 & 7.1 & 17.2 & 3.40 & 4.02 & 3.71 \\
\hline April & 12.0 & 29.9 & 21.0 & 0.29 & 67.0 & 213.0 & 7.9 & 20.5 & 4.00 & 4.78 & 4.39 \\
\hline May & 13.7 & 30.2 & 22.0 & 0.31 & 68.0 & 204.0 & 9.8 & 24.4 & 4.60 & 5.33 & 4.97 \\
\hline June & 15.2 & 30.6 & 22.9 & 0.32 & 72.0 & 200.0 & 11.9 & 27.8 & 5.60 & 5.74 & 5.67 \\
\hline July & 16.0 & 31.0 & 23.5 & 0.31 & 74.0 & 191.0 & 11.4 & 26.8 & 5.40 & 5.56 & 5.48 \\
\hline August & 17.4 & 31.2 & 24.3 & 0.30 & 75.0 & 178.0 & 10.5 & 24.5 & 5.00 & 5.13 & 5.07 \\
\hline September & 17.2 & 31.2 & 24.2 & 0.28 & 71.0 & 182.0 & 8.8 & 20.1 & 4.45 & 4.51 & 4.48 \\
\hline October & 16.7 & 30.3 & 23.5 & 0.26 & 73.0 & 155.0 & 7.7 & 15.9 & 3.40 & 3.50 & 3.45 \\
\hline November & 13.5 & 27.6 & 20.6 & 0.24 & 71.0 & 173.0 & 6.9 & 12.5 & 2.60 & 2.82 & 2.71 \\
\hline December & 10.1 & 24.6 & 17.4 & 0.23 & 66.0 & 204.0 & 6.4 & 10.9 & 2.15 & 2.62 & 2.39 \\
\hline Average & 13.65 & 28.38 & 21.01 & 0.28 & 70.25 & 200.50 & 8.38 & 18.77 & 3.75 & 4.12 & 3.93 \\
\hline
\end{tabular}

whole growth season using well water. This well water is having electric conductivity (ECw) of $7.25 \mathrm{dSm}^{-1}$ and 8.68 SAR (Sodium Adsorption Ratio) and classified as moderately saline irrigation water according to Rhoades et al. (1992). Mulching treatments were with mulching by black plastic sheet $\left(\mathrm{M}_{1}\right)$ and without mulch $\left(\mathrm{M}_{2}\right)$. Drip irrigation system were surface $\left(i_{1}\right)$ and subsurface drip irrigation systems $\left(\mathrm{i}_{2}\right)$

\section{Calculation of Irrigation Water}

\section{Reference crop evapotranspiration}

A reference crop evapotranspiration (ETo, mmday $^{-1}$ ) was calculated as an average between ETo estimating by modified Blaney-Criddle and ETo by estimating Penman-Monteith equations using meteorological data of Experimental Farm,

Faculty of Environmental Agricultural
Sciences, Arish University in El-Arish, Table 1, using the following equations:

Modified Blaney-Criddle equation according to Doorenbos and Pruitt (1984) as follows:

$$
\text { ETo }=c[p(0.46 \mathrm{~T}+8.13)]
$$

Where:

$\mathrm{ETo}=$ reference crop evapotranspiration, $\mathrm{mm}_{\text {day }}{ }^{-1}$.

$\mathrm{T}=$ mean daily temperature, ${ }^{\circ} \mathrm{C}$, over the month considered.

$\mathrm{P}=$ mean daily percentage of total annual daytime hours obtained from Table 1 in Doorenbos and Pruitt, (1984) for a given month and latitude.

$\mathrm{C}=$ adjustment factor which depends on minimum relative humidity, sunshine hours and daytime wind estimates.

Penman-Monteith equation using CROPWAT 8 computer program. 


\section{Crop Evapotranspiration}

Crop evapotranspiration of each growth stage of tomato plants (ETc, $\mathrm{mm} / \mathrm{stage}$ ) was calculated using the duration of tomato stages were 25, 40, 37 and 27 days for initial (i), development (d), flowering (f) and harvesting (h) growth stages, respectively according to Allen et al. (1998). The crop evapotranspiration is estimated as follows equation and illustrated in Table 2:

$$
\mathrm{ETc}=\mathrm{ETo} \times \mathrm{kc}
$$

Where,

$\mathrm{ETc}=$ tomato evapotranspiration, $\mathrm{mm} /$ stage.

$\mathrm{ETo}=$ average between ETo estimating by modified Blaney-Criddle and ETo by estimating Penman-Monteith equations.

$\mathrm{kc}=$ crop factor of tomato growth stages is assumed 1.0.

- Sodium adsorption ratio (SAR) of saline irrigation water sample was calculated according to Richards (1954) using the following equation,

$\mathrm{SAR}=\mathrm{Na}^{+} /\left(\left(\mathrm{Ca}^{++}+\mathrm{Mg}^{++}\right) / 2\right)^{0.5}$

\section{Experimental Design}

Treatments were randomized distributed in complete randomized deign in split-split plot system in three replicates.

\section{Collected Data}

Total yield, $\mathrm{kg} \mathrm{m}^{-2}$

Beginning of harvest on $1^{\text {th }}$ July to $27^{\text {th }}$ July.

\section{Actual Evapotranspiration (ETa)}

To estimate the actual evapotranspiration, $\mathrm{mm}$, at active root depth of tomato plants, the volumetric soil water content of active root depth was determined by the gravimetric method after and before applied irrigation water using the following equation:

$$
\mathrm{ETa}=\left(\square_{1}-\square_{2}\right) \times \mathrm{D}
$$

$\mathrm{ETa}=$ actual evapotranspiration, $\mathrm{mm}$.

$\square_{1}=$ volumetric soil water content after irrigation at active root depth, $\mathrm{m}^{3} \mathrm{~m}^{-3}$.

$\square_{2}=$ volumetric soil water content before irrigation at active root depth, $\mathrm{m}^{3} \mathrm{~m}^{-3}$.

$\mathrm{D}=$ active root depth, $\mathrm{mm}$.

\section{Water use efficiency}

Water use efficiency of crop (WUE), kg $\mathrm{m}^{-3}$, was calculated by dividing the yield, $\mathrm{kg} \mathrm{m}{ }^{-2}$, by actual evapotranspiration, $\mathrm{m}^{3}, \mathrm{~m}^{-2}$, according to Yaron et al. (1973) as follows:

$$
\mathrm{WUE}=\mathrm{Y} / \mathrm{ETa}
$$

Where:

$\mathrm{Y}=$ yield, $\mathrm{kg} \mathrm{m}^{-2}$.

$\mathrm{ETa}=$ actual evapotranspiration, $\mathrm{m}^{3}, \mathrm{~m}^{-2}$.

\section{Statistical Analysis}

The obtained results were subjected to statical analysis of variance. Whereas, the seasons (S), the irrigation systems (I), irrigation treatments $(\mathrm{T})$ and mulching treatments $(\mathrm{M})$ were represented the blocks, main plot factor, subplot factor and sub-subplot factor, respectively. Least significant difference (LSD) test was used for the comparison among treatments means (Steel and Torrie, 1980). CoHort computer program was used for the statistical analysis, version 6.400.

\section{RESULTES AND DISCUSSION}

\section{Tomato Fruit Yield Response to Irrigation Water Regimes and Drip Irrigation Applications}

The results in Table 3 reveal that the tomato fruit yield values $\left((\mathrm{kg} \mathrm{m})^{-2}\right)$ were significantly reduced by increasing the deficit irrigation levels of 0,25 and $50 \%$ ETc individually subjected throughout 
Table 2. Crop evapotranspiration (ETc) and applied irrigation water (AW) for whole season and different tomato plants growth stages as affected by irrigation water regime treatments under surface and subsurface drip irrigation systems

\begin{tabular}{|c|c|c|c|c|c|c|c|c|c|c|}
\hline \multirow{3}{*}{ Treatment } & \multirow{2}{*}{\multicolumn{4}{|c|}{ ETc ( mm/stage) }} & \multicolumn{4}{|c|}{$\begin{array}{l}\text { Applied irrigation water (AW) } \\
\text { (mm/stage) }\end{array}$} & \multirow{2}{*}{\multicolumn{2}{|c|}{$\begin{array}{c}\text { Irrigation } \\
\text { water at whole } \\
\text { season } \\
(\mathbf{m m} / \mathbf{s e a s o n})\end{array}$}} \\
\hline & & & & & & Growt & h stage & & & \\
\hline & $i^{*}$ & $\mathbf{D}$ & $\mathbf{F}$ & $\mathbf{H}$ & $\mathbf{i}$ & $\mathbf{D}$ & $\mathbf{F}$ & $\mathbf{H}$ & ETc & $\mathbf{A W}$ \\
\hline \multicolumn{11}{|c|}{ Surface drip irrigation system } \\
\hline $\mathbf{T}_{1}$ & 102.95 & 189.40 & 204.86 & 147.96 & 168.29 & 309.60 & 334.86 & 241.86 & 644.49 & 1054.6 \\
\hline $\mathbf{T}_{2}$ & 102.95 & 142.05 & 153.64 & 110.97 & 168.29 & 232.20 & 251.15 & 181.40 & 509.61 & 833.0 \\
\hline $\mathbf{T}_{3}$ & 102.95 & 142.05 & 204.86 & 147.96 & 168.29 & 232.20 & 334.86 & 241.86 & 597.82 & 977.2 \\
\hline $\mathbf{T}_{4}$ & 102.95 & 189.40 & 153.64 & 147.96 & 168.29 & 309.60 & 251.15 & 241.86 & 593.95 & 970.9 \\
\hline $\mathbf{T}_{5}$ & 102.95 & 189.40 & 204.86 & 110.97 & 168.29 & 309.60 & 334.86 & 181.40 & 608.18 & 994.1 \\
\hline $\mathbf{T}_{6}$ & 102.95 & 94.70 & 102.43 & 73.98 & 168.29 & 154.80 & 167.43 & 120.93 & 374.06 & 611.4 \\
\hline $\mathbf{T}_{7}$ & 102.95 & 94.70 & 204.86 & 147.96 & 168.29 & 154.80 & 334.86 & 241.86 & 550.47 & 899.8 \\
\hline $\mathbf{T}_{8}$ & 102.95 & 189.40 & 102.43 & 147.96 & 168.29 & 309.60 & 167.43 & 241.86 & 558.40 & 887.2 \\
\hline $\mathbf{T}_{9}$ & 102.95 & 189.40 & 204.86 & 73.98 & 168.29 & 309.60 & 334.86 & 120.93 & 556.40 & 933.7 \\
\hline \multicolumn{11}{|c|}{ Subsurface drip irrigation system } \\
\hline $\mathbf{T}_{1}$ & 102.95 & 189.40 & 204.86 & 147.96 & 168.29 & 292.23 & 316.07 & 228.29 & 644.49 & 996.3 \\
\hline $\mathbf{T}_{2}$ & 102.95 & 142.05 & 153.64 & 110.97 & 168.29 & 219.17 & 237.05 & 171.22 & 509.61 & 787.0 \\
\hline $\mathbf{T}_{3}$ & 102.95 & 142.05 & 204.86 & 147.96 & 168.29 & 219.17 & 316.07 & 228.29 & 597.82 & 923.2 \\
\hline $\mathbf{T}_{4}$ & 102.95 & 189.40 & 153.64 & 147.96 & 168.29 & 292.23 & 237.05 & 228.29 & 593.95 & 917.2 \\
\hline $\mathbf{T}_{5}$ & 102.95 & 189.40 & 204.86 & 110.97 & 168.29 & 292.23 & 316.07 & 171.22 & 608.18 & 939.2 \\
\hline $\mathbf{T}_{6}$ & 102.95 & 94.70 & 102.43 & 73.98 & 168.29 & 146.11 & 158.04 & 114.14 & 374.06 & 577.7 \\
\hline $\mathbf{T}_{7}$ & 102.95 & 94.70 & 204.86 & 147.96 & 168.29 & 146.11 & 316.07 & 228.29 & 550.47 & 850.1 \\
\hline $\mathbf{T}_{8}$ & 102.95 & 189.40 & 102.43 & 147.96 & 168.29 & 292.23 & 158.04 & 228.29 & 558.40 & 838.1 \\
\hline $\mathbf{T}_{9}$ & 102.95 & 189.40 & 204.86 & 73.98 & 168.29 & 292.23 & 316.07 & 114.14 & 556.40 & 882.1 \\
\hline
\end{tabular}


SINAI Journal of Applied Sciences (ISSN: 2314-6079) Vol. (8) Is. (3), Dec. 2019

Table 3. Tomato fruit yield response to irrigation water regimes and drip irrigation applications during first and second growth seasons

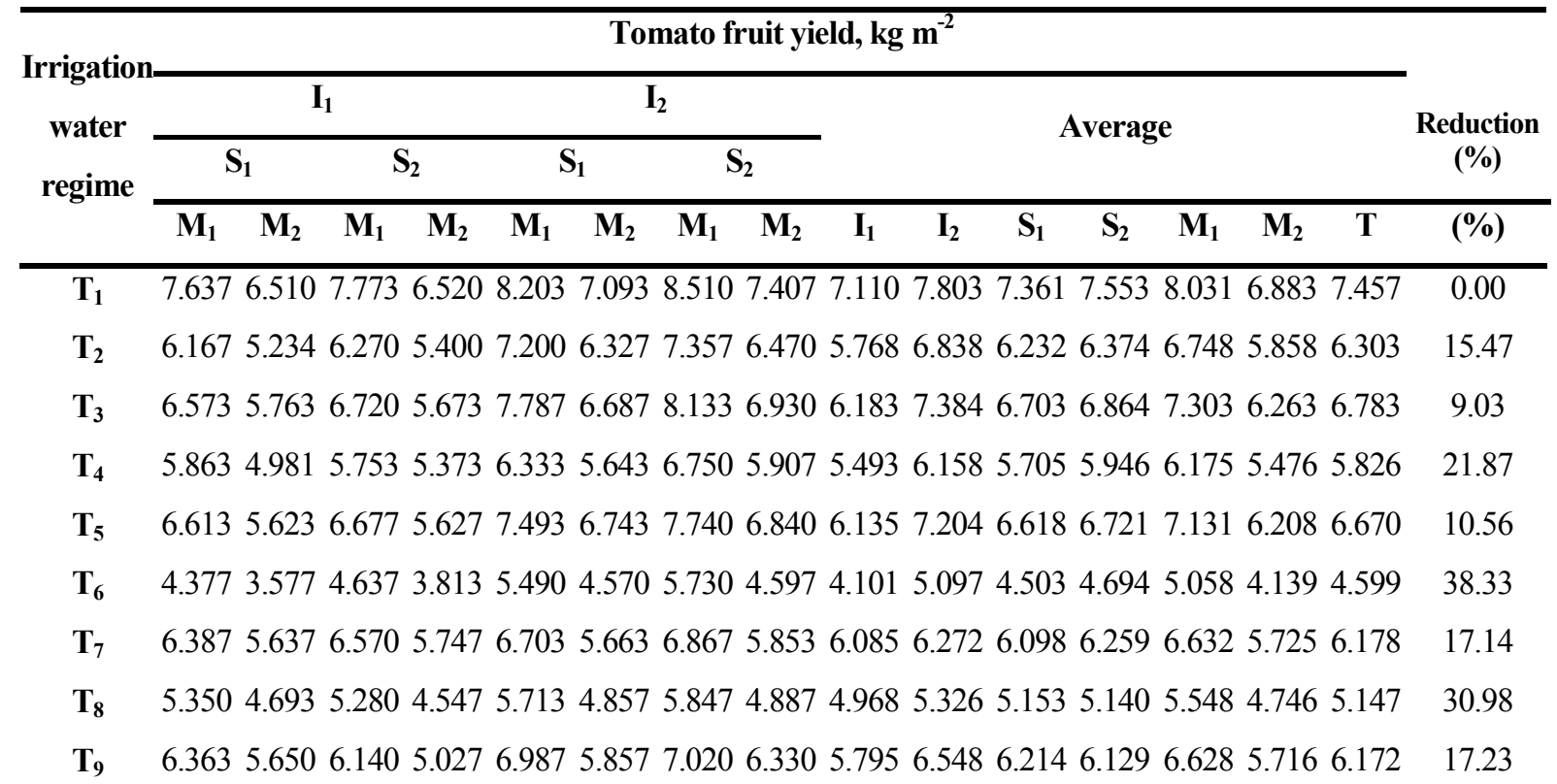

Average 6.1485 .2976 .2025 .3036 .8795 .9387 .1066 .1365 .7376 .5156 .0656 .1876 .5845 .668

LSD 05

1.154

1.154

0.037

0.162

$I_{1}, I_{2}=$ surface and subsurface drip irrigation systems.

$\mathrm{S}_{1}, \mathrm{~S}_{2}=$ first and second growth seasons.

$\mathrm{M}_{1}, \mathrm{M}_{2}=$ with and without mulching.

$\mathrm{T}=$ irrigation water regime.

development, flowering and harvesting growth stages or subjected throughout the whole season using moderately saline water of $7.25 \mathrm{dSm}^{-1}$. This reduction is attributed to the increasing of salt accumulation and decreasing soil water content in active root zone. These results are similar to those reported by Zhang et al. (2017) and Saad et al. (2018).

The sequence of the tomato fruit yield values response to deficit irrigation levels were individually subjected throughout the various growth stages or the whole growth season was in descending order:

$\mathrm{T}_{6}<\mathrm{T}_{8}<\mathrm{T}_{4}<\mathrm{T}_{9}<\mathrm{T}_{7}<\mathrm{T}_{2}<\mathrm{T}_{5}<\mathrm{T}_{3}<\mathrm{T}_{1}$

This sequence is somewhat similar to that obtained for tomato plant height values at the end of harvesting stage. Also, the lowest and highest values of tomato fruit yield were 4.599 and $7.457 \mathrm{~kg} \mathrm{~m}^{-2}$ upon using the deficit irrigation levels of $50 \%$ ETc and 0\% ETc subjected throughout the whole growth season $\left(\mathrm{T}_{6}\right.$ and $\left.\mathrm{T}_{1}\right)$, respectively (Table 3 ).

On the other hand, the obtained results in Table 3 illustrate that tomato fruit yield values response to deficit irrigation levels of 25 and $50 \%$ ETc individually subjected throughout development, flowering and harvesting growth stages or subjected throughout the whole growth season using moderately saline water of $7.25 \mathrm{dSm}^{-1}$, reduced compared to the tomato fruit yield response to the deficit irrigation level of $0 \%$ ETc subjected throughout the whole growth season during the studied seasons. The reduction percentage values in tomato fruit yield were ranged between 9.03-38.33\%.

These results evidenced that the flowering stage is more sensitive to the deficit irrigation 
levels of 25 and $50 \%$ ETc individually subjected throughout the tomato various growth stages than the other growth stages. This result agrees with Doorenbos and Kassam (1986).

Concerning the tomato fruit yield response to mulching treatments, the results in Table 3 elucidate that tomato fruit yield responding with mulching were significantly higher than that obtained without mulching, probably due to the M2 increased the soil salinities hazard and decreased the soil water content in active root zone, thus, the tomato fruit yield values reduced. Also, tomato fruit yield values response with mulching and without mulching were 6.584 and $5.668 \mathrm{~kg} \mathrm{~m}^{-2}$, respectively. This behavior was confirmed with Ngouajio et al. (2007), Rahman et al. (2016) and Singh et al. (2017).

With regard to the tomato fruit yield response to drip irrigation systems, the obtained results showed that tomato fruit yield values under surface drip irrigation system were not significantly less than that obtained under subsurface drip irrigation system (Table 3 ), probably due to that the surface drip irrigation system increased the salt accumulation in the active root zone, so, the tomato fruit reduced. This conclusion is confirmed with El-Mokh et al. (2014). The tomato fruit yield values were 5.737 and $6.515 \mathrm{~kg} \mathrm{~m}^{-2}$ under surface and subsurface drip irrigation systems, respectively (Table 3).

For the season effect, the obtained results in Table 3 show that the tomato fruit yield values during the first season were not significant less than that obtained during second season. These results are closely related with tomato plant growth parameters. Also, the tomato fruit yield values were 6.065 and $6.187 \mathrm{~kg} \mathrm{~m}^{-2}$ during the first and second seasons, respectively.

As for the effect of interaction between water regime treatments, mulching treatments and irrigation systems on the tomato fruit yield, the obtained results revealed that the effect of interaction between studied treatments was significant. The lowest and highest values of tomato fruit yield (3.58 and $8.51 \mathrm{~kg} \mathrm{~m}^{-2}$ ) were obtained at $T_{6} \quad M_{2} I_{1} S_{1}$ and $T_{1} M_{1} I_{2} S_{2}$, respectively, (Table 3 ). Thus, the tomato plants irrigated by the deficit irrigation level of $50 \%$ ETc throughout the whole growth season without mulching under surface drip irrigation system led to reduce the tomato fruit yield

\section{Total Actual Evapotranspiration of Tomato}

The results in Table 4 reveal that the total actual evapotranspiration of tomato plants at the whole growth season values (TETa), $\mathrm{m}^{3} \mathrm{~m}^{-2}$, significantly decreased with increasing the deficit irrigation levels of 0 , 25 and $50 \%$ ETc individually subjected throughout development, flowering and harvesting growth stages or subjected throughout the whole growth season using moderately saline water of $7.25 \mathrm{dSm}^{-1}$. These results are in agreement with Aziz et al. (2013) and Zhang et al. (2017), This decrease is probably due to the decrease of soil water content in active root zone with increasing deficit irrigation levels, Tables $(3 \& 4)$. These results are agreed with those reported by Selim et al. (2013) and Saad $e t$ al. (2018).

The sequence of the tomato TETa values response to studied deficit irrigation levels individually subjected throughout the various growth stages or the whole growth season were in descending order:

$\mathrm{T}_{6}<\mathrm{T}_{8}<\mathrm{T}_{2}<\mathrm{T}_{7}<\mathrm{T}_{9}<\mathrm{T}_{3}<\mathrm{T}_{4}<\mathrm{T}_{5}<\mathrm{T}_{1}$ 
SINAI Journal of Applied Sciences (ISSN: 2314-6079) Vol. (8) Is. (3), Dec. 2019

Table 4. Tomato TETa values response to irrigation water regimes and drip irrigation applications during first and second growth seasons

\begin{tabular}{|c|c|c|c|c|c|c|c|c|c|c|c|c|c|c|c|c|}
\hline \multirow{4}{*}{$\begin{array}{c}\text { Irrigation } \\
\text { water } \\
\text { regime }\end{array}$} & \multicolumn{15}{|c|}{ Tomato TETa, $\mathrm{m}^{3} \mathrm{~m}^{-2}$} & \multirow{3}{*}{$\begin{array}{l}\text { Reduction } \\
\text { (\%) }\end{array}$} \\
\hline & \multicolumn{4}{|c|}{$\mathbf{I}_{1}$} & \multicolumn{4}{|c|}{$\mathbf{I}_{2}$} & \multirow{2}{*}{\multicolumn{7}{|c|}{ Average }} & \\
\hline & \multicolumn{2}{|c|}{$\mathbf{S}_{1}$} & \multicolumn{2}{|c|}{$\mathbf{S}_{2}$} & \multicolumn{2}{|c|}{$S_{1}$} & \multicolumn{2}{|c|}{$\mathbf{S}_{2}$} & & & & & & & & \\
\hline & $\mathbf{M}_{1}$ & $\mathbf{M}_{2}$ & $\mathbf{M}_{1}$ & $\mathbf{M}_{2}$ & $\mathrm{M}_{1}$ & $\mathbf{M}_{2}$ & $\mathrm{M}_{1}$ & $\mathbf{M}_{2}$ & $\mathbf{I}_{1}$ & $\mathbf{I}_{2}$ & $S_{1}$ & $\mathbf{S}_{\mathbf{2}}$ & $\mathbf{M}_{1}$ & $\mathbf{M}_{2}$ & $\mathbf{T}$ & $(\%)$ \\
\hline $\mathbf{T}_{1}$ & 0.585 & 0.608 & 0.580 & 0.606 & 0.550 & 0.531 & 0.549 & 0.595 & 0.595 & 0.556 & 0.569 & 90.583 & 30.566 & 0.585 & 50.576 & 0.00 \\
\hline $\mathbf{T}_{2}$ & 0.452 & 0.500 & 0.455 & 0.490 & 0.431 & 0.465 & 0.420 & 0.460 & 0.474 & 0.444 & 0.462 & 20.456 & 50.440 & 0.479 & 90.459 & 20.22 \\
\hline $\mathbf{T}_{3}$ & 0.510 & 0.571 & 0.526 & 0.573 & 0.482 & 0.546 & 0.486 & 0.541 & 0.545 & 0.514 & 0.527 & 70.532 & 20.501 & 0.558 & 80.529 & 8.01 \\
\hline $\mathbf{T}_{4}$ & 0.534 & 0.579 & 0.518 & 0.566 & 0.498 & 0.541 & 0.492 & 0.531 & 0.549 & 0.516 & 0.538 & 80.527 & 0.511 & 0.554 & 40.532 & 7.49 \\
\hline $\mathbf{T}_{5}$ & 0.558 & 0.587 & 0.549 & 0.591 & 0.527 & 0.549 & 0.519 & 0.565 & 0.571 & 0.540 & 0.555 & 50.556 & 0.538 & 0.573 & 30.556 & 3.45 \\
\hline $\mathbf{T}_{6}$ & 0.318 & 0.341 & 0.324 & 0.358 & 0.283 & 0.312 & 0.328 & 0.362 & 0.335 & 0.321 & 0.314 & 40.343 & 0.313 & 0.343 & 30.328 & 42.96 \\
\hline $\mathbf{T}_{7}$ & 0.468 & 0.513 & 0.473 & 0.515 & 0.446 & 0.481 & 0.464 & 0.523 & 0.492 & 0.479 & 0.477 & 70.494 & 0.463 & 0.508 & 80.485 & 15.66 \\
\hline $\mathbf{T}_{8}$ & 0.439 & 0.483 & 0.460 & 0.502 & 0.409 & 0.446 & 0.434 & 0.476 & 0.471 & 0.441 & 0.444 & 40.468 & 0.436 & 0.477 & 70.456 & 20.74 \\
\hline $\mathbf{T}_{9}$ & 0.524 & 0.560 & 0.523 & 0.563 & 0.497 & 0.526 & 0.491 & 0.542 & 0.543 & 0.514 & 0.527 & 70.530 & 0.509 & 0.548 & 80.528 & 8.21 \\
\hline
\end{tabular}

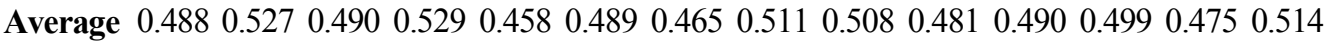

LSD 05

0.076

0.076

$0.002 \quad 0.017$

$\mathrm{I}_{1}, \mathrm{I}_{2}=$ surface and subsurface drip irrigation systems.

$\mathrm{S}_{1}, \mathrm{~S}_{2}=$ first and second growth seasons.

$\mathrm{M}_{1}, \mathrm{M}_{2}=$ with and without mulching.

$\mathrm{T}=$ irrigation water regime.

Table 4 also, the lowest and highest values of tomato TETa $(0.328 \& 0.576$ $\mathrm{m}^{3} \mathrm{~m}^{-2}$ ) were obtained at the deficit irrigation levels of $50 \%$ ETc and $0 \%$ ETc (full irrigation water) subjected throughout the whole season, respectively.

On the other hand, the obtained results showed that tomato TETa values response to deficit irrigation levels of 25 and $50 \%$ ETc individually subjected throughout development, flowering and harvesting growth stages or subjected throughout the whole growth season using moderately saline water of $7.25 \mathrm{dSm}^{-1}$ decreased compared with the tomato TETa value response to the $0 \%$ deficit irrigation level subjected throughout the whole growth season during the studied seasons (Table 4).
The decreased percentage values in tomato TETa were varied from 3.45 to $42.96 \%$. The obtained results revealed that the development stage was more sensitive than that the other growth stages to the deficit irrigation levels of $25 \%$ ETc individually subjected throughout the various tomato growth stages. Also, these results evidenced that the flowering stage was more sensitive than the other growth stages response to the deficit irrigation levels of $50 \%$ ETc individually subjected throughout the various tomato growth stages. These results somewhat agree with Doorenbos and Kassam (1986).

Regarding the tomato TETa response to mulching treatments, the tomato TETa as responded with mulching were significantly 
lower than those obtained without mulching, probably due to that treatment of without mulching increase the soil salinities hazard and decreased the soil water content in active root zone, thus, the tomato TETa values increased. This behavior agrees with Mukherjee et al. (2010). Tomato TETa values as responded with mulching and without mulching treatments were 0.475 and $0.514 \mathrm{~m}^{3} \mathrm{~m}^{-2}$, respectively (Table 4 ).

As for to the tomato TETa response to drip irrigation systems, the obtained results revealed that tomato TETa values under surface drip irrigation system were not significant higher than those obtained under subsurface drip irrigation system (Table 4); probably due to that surface drip irrigation system is promoted the salt accumulation and the evaporation from active root zone. The tomato plants TETa values under surface and subsurface drip irrigation systems were 0.508 and $0.481 \mathrm{~m}^{3} \mathrm{~m}^{-2}$, respectively.

For the season effect, the obtained results showed that the tomato TETa values during the first season were not significant less than that obtained during second season. These results are closely related to soil salinity, soil water content in active root zone and ETa tomato plants at the end of various growth stags. The tomato plants TETa values were 0.490 and $0.499 \mathrm{~m}^{3} \mathrm{~m}^{-2}$ during the irst and second seasons, respectively (Table 4).

Concerning to the effect of interaction between water regimes treatments, mulching treatments and irrigation systems on the tomato TETa values, the obtained results revealed that the effect of interaction between studied treatments was significant. The lowest and highest values of tomato TETa were 0.283 and $0.608 \mathrm{~m}^{3} \mathrm{~m}^{-2}$ obtained at $T_{6} M_{1} I_{2} S_{1}$ and $T_{1} M_{2} I_{1} S_{1}$, respectively,
(Table 4). These results indicated that the use of deficit irrigation level of $50 \%$ ETc individually subjected throughout the whole growth season with mulching and subsurface drip irrigation system will led to reduce the TETa values. Consequently, the tomato water use efficiency increased.

\section{Tomato Water Use Efficiency}

The illustrated results in Table 5 reveal that the water use efficiency values of tomato plants (WUE), $\mathrm{kg} \mathrm{m}^{-3}$, significantly decreased in general with increasing the deficit irrigation levels of 0,25 and $50 \%$ ETc individually subjected throughout development, flowering and harvesting growth stages or subjected throughout the whole growth season using moderately saline water of $7.25 \mathrm{dSm}^{-1}$, these results are in agreement with Patanèa et al. (2011), Aziz et al. (2013) and Delazari et al. (2019). However, the WUE values of tomato plants response to the deficit irrigation levels to 25 and $50 \%$ ETc subjected throughout the whole growth season $\left(\mathrm{T}_{2}\right.$ and $\mathrm{T}_{6}$ ) were increased. The decreases may be attributed mainly to the decrease of applied irrigation water amounts and partially to increase salt accumulation in active root zone with increasing the deficit irrigation levels, thus the tomato fruit yield values were reduced.

The sequence of the tomato WUE values response to deficit irrigation levels individually subjected throughout the various growth stages or the whole growth season was in ascending order:

$\mathrm{T}_{6}>\mathrm{T}_{2}>\mathrm{T}_{1}>\mathrm{T}_{3}>\mathrm{T}_{7}>\mathrm{T}_{5}>\mathrm{T}_{9}>\mathrm{T}_{8}>\mathrm{T}_{4}$

Table 5 also, the lowest and highest values of WUE (11.022 and $14.179 \mathrm{~kg} \mathrm{~m}^{-3}$ ) were obtained at the deficit irrigation level of 25 individually subjected throughout the flowering stage $\left(\mathrm{T}_{4}\right)$ and level of $50 \%$ ETc 
SINAI Journal of Applied Sciences (ISSN: 2314-6079) Vol. (8) Is. (3), Dec. 2019

Table 5. Tomato water use efficiency response to irrigation water regimes and drip irrigation applications during first and second growth seasons

\begin{tabular}{|c|c|c|c|c|c|c|c|c|c|c|c|c|c|c|c|c|}
\hline \multirow{4}{*}{$\begin{array}{c}\text { Irrigation } \\
\text { water } \\
\text { regime }\end{array}$} & \multicolumn{15}{|c|}{ WUE, $\mathrm{kg} \mathrm{m}^{-3}$} & \multirow{3}{*}{$\begin{array}{l}\text { Reduction } \\
(\%)\end{array}$} \\
\hline & & 1 & $I_{1}$ & & & & $I_{2}$ & & \multirow{2}{*}{\multicolumn{7}{|c|}{ Average }} & \\
\hline & \multicolumn{2}{|c|}{$S_{1}$} & \multicolumn{2}{|c|}{$\mathbf{S}_{2}$} & \multicolumn{2}{|c|}{$S_{1}$} & \multicolumn{2}{|c|}{$\mathbf{S}_{2}$} & & & & & & & & \\
\hline & $\mathbf{M}_{1}$ & $\mathbf{M}_{2}$ & $\mathbf{M}_{1}$ & $\mathbf{M}_{2}$ & $\mathbf{M}_{1}$ & $\mathbf{M}_{2}$ & $\mathbf{M}_{1}$ & $\mathbf{M}_{2}$ & $\mathbf{I}_{1}$ & $\mathbf{I}_{\mathbf{2}}$ & $\mathbf{S}_{1}$ & $\mathbf{S}_{\mathbf{2}}$ & $\mathbf{M}_{1}$ & $\mathbf{M}_{2}$ & $\mathbf{T}$ & $(\%)$ \\
\hline $\mathrm{T}_{1}$ & 13.05 & 10.71 & 13.40 & 10.76 & 14.92 & 13.36 & 15.50 & 12.45 & 11.98 & 14.06 & 13.01 & 13.03 & 14.22 & 11.82 & 13.02 & 0.00 \\
\hline $\mathbf{T}_{2}$ & 13.64 & 10.47 & 13.78 & 11.02 & 16.71 & 13.61 & 17.52 & 14.07 & 12.23 & 15.47 & 13.61 & 14.10 & 15.41 & 12.29 & 13.85 & -6.39 \\
\hline $\mathbf{T}_{3}$ & 12.89 & 10.09 & 12.78 & 9.90 & 16.15 & 12.25 & 16.74 & 12.81 & 11.41 & 14.49 & 12.85 & 13.06 & 14.64 & 11.26 & 12.95 & 0.52 \\
\hline $\mathbf{T}_{4}$ & 10.98 & 8.60 & 11.11 & 9.49 & 12.72 & 10.43 & 13.72 & 11.12 & 10.05 & 12.00 & 10.68 & 11.36 & 12.13 & 9.91 & 11.02 & 15.33 \\
\hline$T_{5}$ & 11.85 & 9.58 & 12.16 & 9.52 & 14.22 & 12.28 & 14.91 & 12.11 & 10.78 & 13.38 & 11.98 & 12.18 & 13.29 & 10.87 & 12.08 & 7.21 \\
\hline $\mathbf{T}_{6}$ & 13.76 & 10.49 & 14.31 & 10.65 & 19.40 & 14.65 & 17.47 & 12.70 & 12.30 & 16.05 & 14.57 & 13.78 & 16.24 & 12.12 & 14.18 & -8.91 \\
\hline $\mathbf{T}_{7}$ & 13.65 & 10.99 & 13.89 & 11.16 & 15.03 & 11.77 & 14.80 & 11.19 & 12.42 & 13.20 & 12.86 & 12.76 & 14.34 & 11.28 & 12.81 & 1.60 \\
\hline $\mathbf{T}_{8}$ & 12.19 & 9.72 & 11.48 & 9.06 & 13.97 & 10.89 & 13.47 & 10.27 & 10.61 & 12.15 & 11.69 & 11.07 & 12.78 & 9.98 & 11.38 & 12.59 \\
\hline $\mathbf{T}_{9}$ & 12.14 & 10.09 & 11.74 & 8.93 & 14.06 & 11.13 & 14.30 & 11.68 & 10.73 & 12.79 & 11.86 & 11.66 & 13.06 & 10.46 & 11.76 & 9.67 \\
\hline Average & 12.68 & 10.08 & 12.74 & 10.05 & 15.24 & 12.26 & 15.38 & 12.04 & 11.39 & 13.73 & 12.57 & 12.55 & 14.01 & 11.11 & & \\
\hline LSD 05 & - & & - & - & & - & . & . & 0.3 & & 0.3 & 34 & 0.0 & 84 & 0.733 & \\
\hline
\end{tabular}

$\mathrm{I}_{1}, \mathrm{I}_{2}=$ surface and subsurface drip irrigation systems.

$\mathrm{S}_{1}, \mathrm{~S}_{2}=$ first and second growth seasons.

$\mathrm{M}_{1}, \mathrm{M}_{2}=$ with and without mulching.

$\mathrm{T}=$ irrigation water regime.

individually subjected throughout the whole growth season $\left(\mathrm{T}_{6}\right)$, respectively. On the other hand, the obtained results showed that tomato WUE values response to deficit irrigation levels of 25 and $50 \%$ ETc individually subjected throughout development, flowering and harvesting growth stages subjected throughout the whole growth season using moderately saline water of $7.25 \mathrm{dSm}^{-1}$ decreased generally compared with the tomato WUE value response to the deficit irrigation subjected throughout the whole growth season during the studied seasons (Table 5). However, the WUE values of tomato plants were obtained at deficit irrigation level of 25 and $50 \%$ ETc individually subjected throughout the whole growth season $\left(\mathrm{T}_{2}\right.$ and $\mathrm{T}_{6}$ ), respectively, where, the WUE values were increased (6.39-8.91\%). The decrease percentage values in tomato WUE were varied between $0.52-15.33 \%$.
Also, these results evidenced that the tomato flowering stage was more sensitive than other growth stages to the deficit irrigation levels of 25 and $50 \%$ ETc individually subjected throughout various tomato growth stages. These results are completely confirmed with the results of tomato fruit yield and agreed with Doorenbos and Kassam (1986).

As for the tomato WUE response to mulching treatments, tomato WUE response with mulching was significantly higher than that of without mulching (Table 5); probably due to that the treatment of without mulching decreased the soil water content and increased the soil salinities hazard in active root zone, thus the tomato fruit yield values were reduced. Tomato WUE values response with mulching and without mulching treatments were 14.011 and $11.111 \mathrm{~kg} \mathrm{~m}^{-3}$, respectively (Table 5). 
With regard to the tomato WUE response to drip irrigation systems, the obtained results in Table 5 reveal that tomato WUE values under surface drip irrigation system were significantly less than those obtained under subsurface drip irrigation system. This behavior is probably due to that surface drip irrigation system decreased soil water content and promoted the salt accumulation in the active root zone, thus the tomato fruit yield values were reduced, Table 3 and the tomato TETa values were increased (Table 5). This conclusion is in agreement with Taylor et al. (2006) and El-Mokh et al. (2014).

The tomato WUE values were 11.390 and $13.732 \mathrm{~kg} \mathrm{~m}^{-3}$ under surface and subsurface drip irrigation systems, respectively (Table 5).

For the season effect, the obtained results showed that the tomato WUE values during the first season were not significant higher than that obtained during second season. Tomato WUE values were 12.567 and $12.554 \mathrm{~kg} \mathrm{~m}^{-3}$ during the first and second seasons, respectively.

As for the effect of interaction between water regime treatments, mulching treatments and drip irrigation systems on the tomato WUE values, the obtained results revealed that the effect of interaction between studied treatments was significant. The lowest and highest values of tomato WUE (8.60 and $19.40 \mathrm{~kg} \mathrm{~m}^{-3}$ ) were obtained at $\mathrm{T}_{4}$ $\begin{array}{llllllll}M_{2} & I_{1} & S_{1} & \text { and } & T_{6} & M_{1} & I_{2} & S_{1} \text {, respectively }\end{array}$ (Table 5). These results indicated that the tomato plants irrigated by the deficit irrigation water level of $25 \%$ ETc individually subjected throughout the flowering stage without mulching with surface drip irrigation system led to decrease the values of WUE. Although, the tomato fruit yield values were low, the applied deficit irrigation level of $50 \%$ throughout the whole growth season with mulching and subsurface drip irrigation system, the tomato WUE values] led to higher the values of WUE; probably the tomato plants that low consumed water $\left(\right.$ TETa $=0.328 \mathrm{~m}^{3} \mathrm{~m}^{-2}$ ) under this deficit irrigation level.

\section{REFERENCES}

\section{Abuarab, M.; Ehab, M. and Mohamed, I.} (2013). Effect of air injection under subsurface drip irrigation on yield and water use efficiency of corn in a sandy clay loam soil. J. Advanc. Res., 4: 493499

Agbna, G.H.D.; Dongli, S.; Zhipeng, L.; Elshaikh, N.A.; Guangcheng, S. and Timm, L.C. (2017). Effects of deficit irrigation and biochar addition on the growth, yield, and quality of tomato. Sci. Hort., 222: 90-101

Allen, R.G.; Pereira, L.S.; Raes, D. and Smith, M. (1998). Crop Evapotranspiration Guidelines for Computing Crop Water Requirements. Irrigation and Drainage Paper 56, FAO, Rome.

Arbex, C.V.; Page, D.; Giovinazzo, R.; Bertin, N. and Fanciullino, A.L. (2017). Combined effects of irrigation regime, genotype, and harvest stage determine tomato fruit quality and aptitude for processing into Puree. Frontiers in Plant Sci., 8: 17-25.

Aziz, S.A.; Ahmad, T.S.; Rasheed, A.B.; Sharef, B.H. and Talb, H.D. (2013). The impacts of deficit irrigation levels and intervals on tomatoes and eggplants yield in un-conditions plastic house. J. Zankoy Sulaimani - Part A. 15 (2): 125 135. 
Banerjee, H.; Puste, A.M.; Ray, K.; Sarkar, S.; Chakraborty, A. and Rana, L. (2016). Influence of irrigation levels and mulching on growth, water use, yield, economics and quality of potato (Solanum tuberosum) under new alluvial soil of West Bengal. Indian J. Agron., 61 (3): 377-383.

Biswas, S.K.; Akanda, A.R.; Rahman, M.S. and Hossain, M.A. (2015). Effect of drip irrigation and mulching on yield, water-use efficiency and economics of tomato. Plant, Soil and Environ., 61 (3): 97-102.

Delazari, F.; Gomes, R.S.; Laurindo, B.S.; Laurindo, D.F. and Giovanelli, B. (2019). Establishing irrigation levels targeting higher content of lycopene and water use efficiency in tomato. J. Agri. Sci., 11 (1): 209-219.

Doorenbos, J. and Kassam, A.H. (1986). Yield Response to Water. Irrigation and Drainage Paper 33. FAO, Rome.

Doorenbos, J. and Pruitt, W.O. (1984). Crop Water Requirements. Irrigation and Drainage paper 24. FAO, Rome.

El-Mokh, F.; Nagaz, K.; Moncef, M.; Netij, M. and Mechlia, B. (2014). Effects of surface and subsurface drip irrigation regimes with saline water on yield and water use efficiency of potato in arid conditions of Tunisia. J. Agric. Environ. Int. Develop., 108 (2): 227-246.

Hanson, B. and May, D. (2004). Effect of subsurface drip irrigation on processing tomato yield, water table depth, soil salinity, and profitability. Agric. Water Manag., 68: 1-17.

Hassanli, A.M.; Ebrahimizadeh, M.A. and Beecham, S. (2009). The effects of irrigation methods with effluent and irrigation scheduling on water use efficiency and corn yields in an arid region. Agric. Water Manag., 96: 93-99.

Hoorn, J.W.; Katerji, N.; Hamdy, A. and Mastrorilli, M. (1993). Effect of saline water on soil salinity and on water stress, growth, and yield of wheat and potatoes Agric. Water Manag., 23: 247-265

Mukherjee, A.; Kundu, M. and Sarkar, S. (2010). Role of irrigation and mulch on yield, evapotranspiration rate and water use pattern of tomato (Lycopersicon esculentum L.). Agric. Water Manag., 98: 182-189.

Nangare, D.D.; Singh, Y.; Kumar, P.S. and Minhas, P.S. (2016). Growth, fruit yield and quality of tomato (Lycopersicon esculentum Mill.) as affected by deficit irrigation regulated on phenological basis. Agric. Water Manag., 171: 73-9.

Ngouajio, M.; Wang, G. and Goldy, R. (2007). With holding of drip irrigation between trans-planting and flowering increases the yield of field-grown tomato under plastic mulch., Agric. Water Manag., 87: 285-291.

Patanèa, C.; Tringali, S. and Sortino, $O$. (2011). Effects of deficit irrigation on biomass, yield, water productivity and fruit quality of processing tomato under semi-arid Mediterranean climate conditions. Sci. Hort., 129: 590-596.

Poornima, R.P.; Mallika, K. and Satish Kumar, U. (2016). Cucumber (Cucumis sativus, L.) water use efficiency under plastic mulch and drip irrigation: a review. Int. J. Soc. Sci. Develop., 11: 3765-3767

Rahman, M.J.; Quamruzzaman, M. and Samsuddin, M. (2016). Effect of different mulch materials on growth and 
yield of tomato. Bangladesh. Hort., 2: 29-37.

Rhoades, J.D.; Kandiah, A. and Mashali, A.M. (1992). The use of saline waters for crop production. Irrigation and Drainage Paper 48, FAO Rome, Italy.

Richards, L.A. (1954). Diagnosis and Improvement of Saline and Alkaline Soils, USA, Dept. Agric., Handbook No. 60 .

Saad, A.F.; Shalaby, A.A. and Mokhtar, A.M. (2018). Influence of deficit irrigation using saline water on yield of tomato under two irrigation systems, Alex. Sci. Exch. J., 39 (1): 35-47.

Selim, T.; Bouksila, F.; Berndtssonand, R. and Persson, M. (2013). Soil water and salinity distribution under different treatments of drip irrigation. Soil Sci. Soc. Ame. J., 77 (4): 1144-1156.

Sharma, S.P.; Daniel, I.L.; Kevin, M.C.; Volderb, A. and Ibrahim, A.M.H. (2014). Root growth, yield, and fruit quality responses of reticulatus and inodorus melons (Cucumis melo L.) to deficit subsurface drip irrigation, Agric. Water Manag., 136: 75-85.

Singh, H.; Parveen, S.; Pardeep, K.; Navjot, S.D. and Bhallan, S.S. (2017). Influence of mulching on growth and yield of tomato (Solanum lycopersicum
L.) under protected environment. Biotechn. J. Int., 19 (2): 1-6.

Steel, R.G.D. and Torrie, J.H. (1980). Principles and Procedures of Statistics. McGraw-Hill, New York. Van.

Taylor, K.S.; Anda, M.; Sturman, J.; Mathew, K. and Ho, G. (2006). Subsurface drip line tubing-an experimental design for assessing the effectiveness of using drip line to apply treated wastewater for turf irrigation in Western Australia. Desalination., 187: 375-385.

Yaron, B.; Danfors, E. and Vaddia, Y. (1973). Arid Zone Irrigation. SpringerVerlag Berlin, Heidelberg, New York.

Zhang, H.; Xionga, Y.; Huanga, G.; Xua, X. and Huanga, Q. (2017). Effects of water stress on processing tomatoes yield, quality and water use efficiency with plastic mulched drip irrigation in sandy soil of the Hetao Irrigation District., Agric. Water Manag., 179: 205-214.

Zotarelli, L.; Scholberg, J.M. and Dukes, M.D. (2009). Tomato yield, biomass accumulation, root distribution and irrigation water use efficiency on a sandy soil, as affected by nitrogen rate and irrigation scheduling. Agric. Water Manag., 96: 23-34. 


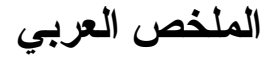

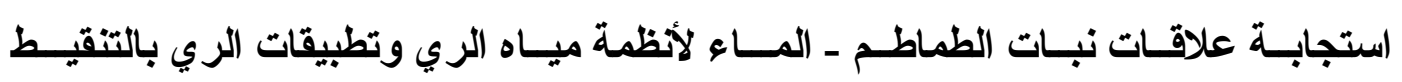 \\ إسر اء عادل رحيمه"'، محمد سعد القصاص'، عادل أبو شعيشع شلبي'، عطيه عبدالوهاب السبسي'

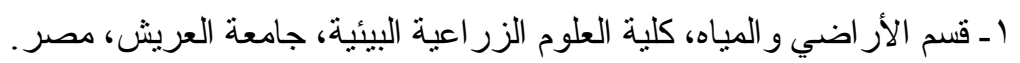

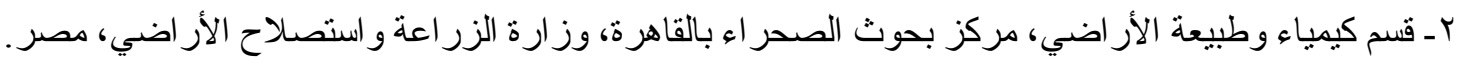

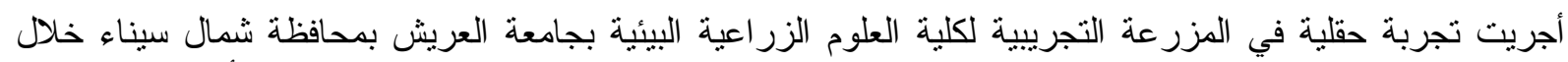

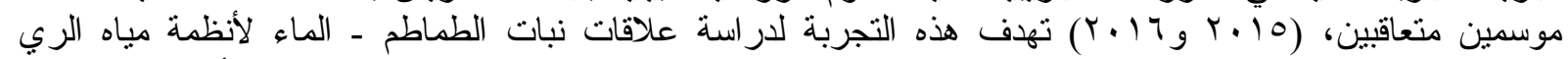

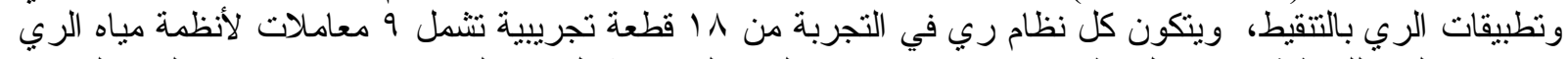

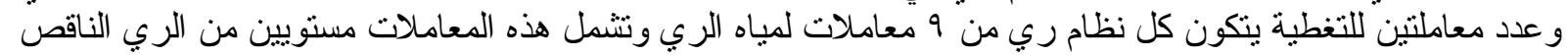

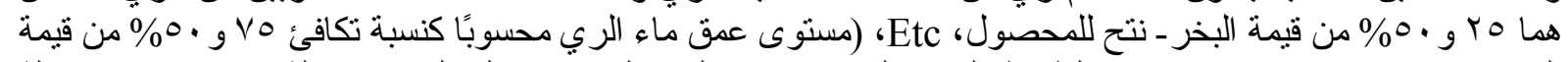

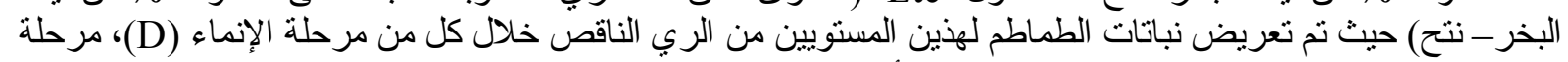

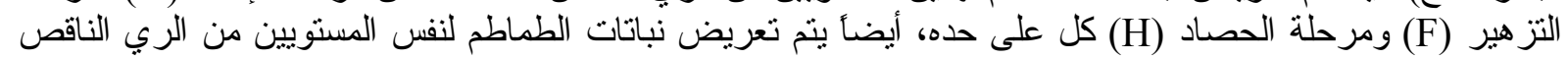

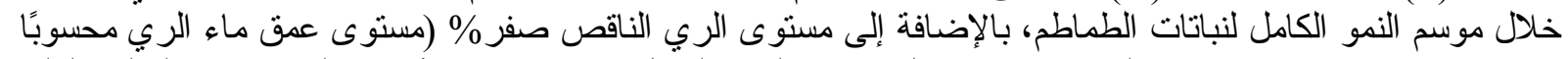

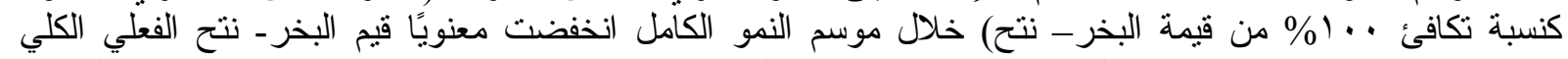

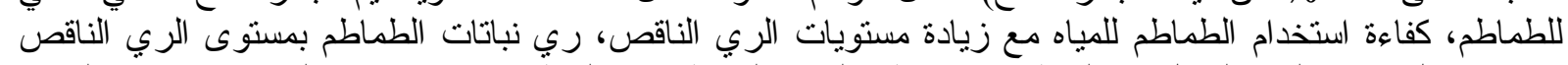

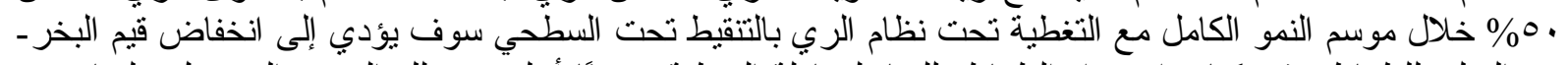

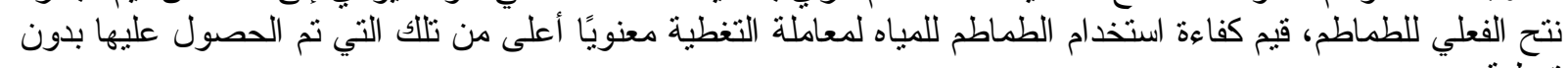
تغطية.

الكلمات الإرشادية: محصول الطماطم، البخر - نتح الفعلي الكلي، قيم كفاءة استخدام الطماطم للمباه، أنظمة مياه الري،

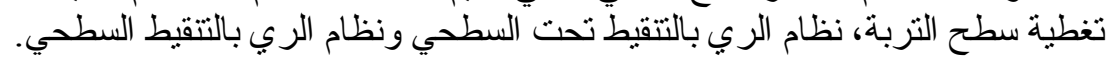




\section{Rehema, et al.}

